\title{
An Approach to Conversion Disorder with Comorbid Major Depression Using Pharmacotherapy and Psychodrama Techniques: A Case Report
}

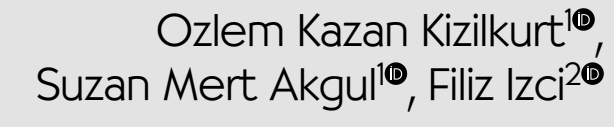

'Istinye State Hospital, Department of Psychiatry, Istanbul - Turkey

${ }^{2}$ Istanbul Bilim University, Department of Psychiatry, Istanbul - Turkey

\section{ABSTRACT}

An approach to conversion disorder with comorbid major depression using pharmacotherapy and psychodrama techniques: a case report

Conversion disorder (CD) is a psychiatric disorder commonly seen in clinical and emergency psychiatry departments; it may occur with psychological factors and lead to changes in motor and sensory functioning in a way that suggests a physical disorder. Multiple mental illnesses such as depressive disorder can accompany CD. In addition to antidepressant or antipsychotic drug treatments, psychotherapy techniques can be applied in the treatment of CD. In this report, we aim to present a case of major depressive disorder with accompanying CD where we intervened applying drug therapy together with psychodrama techniques, a type of psychotherapy that is not frequently used in CD.

Keywords: Conversion disorder, prognosis, psychodrama

\section{öz}

Majör depresyon eş tanısı bulunan bir konversiyon bozukluğu olgusuna farmakoterapi ve psikodrama teknikleri ile yaklaşım: Bir olgu sunumu

Psikolojik etkenlerle ortaya çıkabilen, fiziksel bir bozukluğu düşündürecek biçimde motor ve duyusal işlevsellikte değişikliklerle giden konversiyon bozukluğu (KB) psikiyatri klinik ve acil servislerinde sık görülen bir ruhsal hastalıktır. KB'ye depresif bozukluk gibi birden çok ruhsal hastalıkta eşlik edebilmektedir. KB'nin tedavisinde antidepresan, antipsikotik ilaç tedavileri yanında psikoterapi teknikleri de uygulanabilmektedir. Bu makalede, KB'ye eşlik eden majör depresif bozukluk tanıları bulunan, ilaç tedavisi ile beraber KB'de sık kullanılmayan bir psikoterapi türü olan psikodrama teknikleri uygulayarak yanıt aldığımız bir olguyu sunmayı amaçladık.

Anahtar kelimeler: Konversiyon bozukluğu, seyir, psikodrama

How to cite this article: Kazan-Kizilkurt $O$, MertAkgul S, Izci F. An approach to conversion disorder with comorbid major depression using pharmacotherapy and psychodrama techniques: a case report. Dusunen Adam The Journal of Psychiatry and Neurological Sciences 2018;31:413-420. https://doi.org/10.5350/DAJPN2018310412

\section{INTRODUCTION}

C onversion disorder (CD) is a condition triggered by psychological factors mimicking particularly neurological disorders affecting motor or sensory functions with one or more symptoms and deficits that are not consistent with the known anatomical structure of the central or peripheral nervous system (1). While gradually decreasing in Western countries, CD is still frequently seen in Turkey, accounting for $12-47 \%$ of patients presenting to the psychiatric emergency policlinics $(2,3)$.

In the etiology of $\mathrm{CD}$, various psychodynamic views, neurobiological and genetic factors, and sociocultural perspectives have been discussed; studies usually conclude that it is a multifactorial condition $(4,5)$. Studies examining the role of traumas and emotional stress in early childhood have found correlations especially of 
life events in the socio-professional area and the experience of bad treatment in early childhood with conversion symptoms (6). From a psychodynamic perspective, any loaded experience may disturb the balance reached by an effective suppression of the impulse. In such a case, the repression used by the ego proves insufficient and a state of conflict arises. Against the anxiety provoked by the conflict, a new mechanism is needed, which in a hysterical neurosis is a conversion or dissociation mechanism (7). The literature reports that other mental disorders frequently accompany CD (8-10). A study by Bowman and Markand (11) stated that CD may be comorbid with depressive disorder in $88 \%$ of cases and conversion symptoms might be a prodrome for anxiety.

In the therapy of CD, antidepressant and antipsychotic drugs are used alongside rehabilitation methods such as psychoanalytic and cognitivebehavioral psychotherapy, exercise, functional electrical stimulation (FES), or biofeedback $(12,13)$. It has been reported that psychotherapy is useful for most patients (14). The therapeutic importance of a psychodynamic perspective in determining and addressing problematic areas in family relationships (15) and of cognitive-behavioral therapy methods such as the development of cognitive coping skills, cognitivebehavioral family interventions, relaxation exercises, positive reinforcement of healthy behavior, and extinguishing sick role behavior have been emphasized (16).

Another therapy technique that can be used in the treatment is psychodrama, which is a psychotherapy method founded in the 1920s by Jacob Levy Moreno (17), making use of spontaneous theater. It uses dramatization and role-playing techniques, exploring individuals' lives through reenacting their actions by way of dramatic selfpresentation. The aim of this method is to reach catharsis, gain insight, and direct the protagonist towards healthier behaviors (18). Moreno's psychodrama technique is applied both in individual and in group therapy; individual psychodrama is known as monodrama. While the literature mentions an increase in the application of psychodrama, knowledge about monodrama is still limited and mainly based on case reports and observational data. According to these data, monodrama technique has been shown to be an effective therapy method in grief reaction (19), anorexia nervosa (20), obsessive-compulsive disorder (21), borderline personality organization (22), and in anxiety disorders, obsessive-compulsive personality and traumatic experiences (23). In addition, it has been established that monodrama applications not only resolve symptoms in a way similar to group psychodrama, but are also helpful in liberating mental growth, enrichment, and imagination (24). CD symptoms may also be seen as a medium for emotions and thoughts that are forbidden to be understood due to cultural characteristics. These symptoms allow an expression via "body language" of feelings and ideas that cannot be expressed in spoken words (25). It can be assumed that reaching catharsis with psychodrama techniques based upon the spontaneous acting out of previously unplanned emotions and thoughts, facilitating the expression of unspoken feelings and thoughts with the help of these techniques, and the achievement of insight can be beneficial in CB therapy.

This report presents a case followed with a diagnosis of $\mathrm{CB}$ and simultaneous major depression, treated with pharmacotherapy and individual psychodrama techniques. Our intention is to draw attention to the diagnosis of $\mathrm{CB}$, a condition that is easily missed especially in emergency services, and we want to assess the positive response given to psychodrama techniques applied in the therapy.

\section{CASE}

A 37-year-old female patient was referred from the neurology clinic to the psychiatry policlinic with seizure-like findings that had been occurring for 5 months, with increasing frequency especially during the last 1 month. The seizures mostly started after exposure to a stressor, starting with fainting on the spot, followed by whole-body spasms, lack of response to verbal stimuli, and emission of meaningless sounds for the duration of 10-15 minutes. The patient complained of having been unhappy, 
unmotivated, and fatigued for the last year; she did not enjoy life and permanently wanted to sleep. In the previous week, she had seen her younger sister's face as a snake face, which lasted for 1-2 minutes; similarly, in the last years she sometimes had briefly perceived her surroundings and some of her own body parts, especially her hands, different from what they were, as if her experiences and what was said were not real, and sometimes she saw objects different from what they were. However, these events passed after a short while, which is why she said she did not pay them much attention. Neurological examination was normal, biochemical and hematological workups and imaging test results did not find any internal or neurological pathologies to explain the symptoms; therefore, she was referred to our policlinic. Our patient was treated for comorbid $\mathrm{CD}$ and major depression accompanied by symptoms of depersonalization/derealization. In the psychiatric consultation, in order to establish the factors that triggered and perpetuated the disease symptoms, we investigated her life and family history and stress factors in a detailed manner.

In the patient's history, we learned that 1 year ago she had found out that her husband had a relation with her sister, and she began to live separated from her husband, at which point depressive and conversive complaints started. Particularly after events or conversations reminding her of the relationship between her sister and her husband, she said that her body became empty; she fainted on the spot, her arms and legs cramped, and though she perceived her surroundings, she was unable to react to them and stayed locked. These faintings became more frequent in the last month, happening every one or two days, and sometimes being followed by fits of crying. One year ago, the patient had decided to terminate her marriage of 12 years and filed for divorce. With her 10-year-old son, she lived in the house where she had been staying with her husband before the separation, close to her family's place. She stated that they had married willingly, but during their married lives, they had permanently suffered from economic problems; her husband did not fulfil his responsibilities, but she had never been troubled by anything and loved him very much. She blamed herself for the fact that her husband had cheated on her with her sister because she might not have shown him enough attention, but nevertheless she could not accept the situation. While they were engaged, she had experienced problems with her husband's family, feeling that they did not accept her, and therefore throughout her marriage, she had avoided seeing them and tried to stay as far away from them as possible. When we evaluated the patient's personal traits, we found her to be introverted, with difficulties to express her feelings, and sensitive. Repression, disassociation, and conversion mechanisms were evaluated as basic defense mechanisms. The patient had no known history of disease, did not use any medications, and there were no abnormalities in her family history.

In the mental state examination, the patient appeared age-appropriate, with good self-care. She was conscious, cooperative, and established eye contact. She was fully oriented to place, time, and person. No memory or perception impairments were found. Judgment, abstraction, and sense of reality were normal. Her speech was slow and comprehensible. Psychomotor activity and amount of speech were normal. Her mood was depressive, her affectivity problematic and depressed. She had a distinct reduction of sleep, appetite, and sexual drive. Her thought content was dominated by hatred towards her sister and her husband. Her score on the Hamilton Depression Ration Scale (HAM-D) was 26, on the Brief Psychiatric Rating Scale (BPRS) was 27. She was followed as an outpatient at the psychiatry policlinic with a drug treatment using escitalopram $10 \mathrm{mg} /$ day, increased during control visits to $20 \mathrm{mg} /$ day. It was agreed that she would come in for control every other week, and at the same time she started monodrama sessions, a kind of individual psychotherapy using warm-up, action, and sharing techniques, with an experienced psychotherapist. Considering that she might display variability over the course of the treatment, a therapy duration of 6 months was scheduled.

In the second session of the therapy, the patient, who mentioned that she was permanently nervous and 
quick to become angry, was asked to express this anger in a picture. She drew a volcano in the middle of the paper and then added a path climbing up the mountain, explaining that she had gone up to the edge of the volcano following that path. At the end of the path, she drew herself and her sister and said that while her sister was standing there, the volcano broke out in flames. When the therapist asked her what she wanted to do in this situation, she drew a layer of soil over the volcano, saying that she wanted to close the volcano. She stated that she finally wanted to give her life a new direction and no longer think about her sister. In the same session, she explained that she wanted to save herself from what she had lived through, close everything up and get on with her life. It was seen that she had avoided to talk about her feelings in the process. The patient's conversive and depressive symptoms continued and her scores on the scales showed only a minimal improvement (HAM-D=22; BPRS=22).

In the summer, when the time came to slaughter the chicks she had bred and brought up in the garden of their house, she said that she was not able to kill them and under tears disbanded the henhouse. In the session where she told this event, she said that she did not want to see anyone and was not motivated to do anything. It was thought that the scattered henhouse symbolically reminded her of her scattered old family. She said her sister had dispersed her family, starting to cry. She talked about the hatred she felt for her sister and continued to cry for a long period. A scene was created where she imagined talking to her sister, and she was able to convey her feelings towards her sister.

In a session where she began by explaining that everything she had piled up in her life had collapsed, she was asked to use the objects in the consultation room to express and animate her statement. She placed a piece called her sister at the bottom, and on top of it she placed in turn happiness, her son, and her parents. When looking at the situation from outside, she realized that the piled-up pieces were on top of her sister, and she wanted to separate the piece she had called her sister from the other objects. She placed another piece called logic in the side remaining after she seperated the piece representing her sister. When she was asked what she felt when looking at both sides, she said that she felt hatred when looking at the object representing her sister and calm on the other side. She added two more pieces on the side that she had defined as positive: knitting and looking after her son's lessons, and she realized that her change in behavior could increase the positive side.

When she met with a lawyer to file for divorce from her husband, her complaints of lack of energy and motivation partly increased. She said that she felt unhappy and hardly wanted to leave the house. In the process, she was able to gain insight into the relation between herself and her husband by role-reversal. She realized that the relationship between her husband and her sister was not her fault; during their marriage, they had experienced many problems, and while she had been an understanding spouse, she sometimes had found it difficult to express her feelings. There had been many issues she was not able to talk about with her husband, and they had gone through communication problems.

In further sessions, she reported that she had wanted to tell her mother about what was going on, but she had not known how to explain things and feared that her mother was not going to believe her. At this point, future projection technique was applied and a conversation with the mother attempted. On an empty chair, she first assumed her mother's role, and then she took over her own role and conveyed to her mother what was going on inside her. In this scene, she explained to her mother the problems and feelings she had experienced during her marriage and said that she needed her support and wanted her to be by her side. After that session, she talked to her mother and told her about the relationship between her husband and her sister. Her mother was deeply saddened but hugged and comforted her. From that day, her relation with her mother improved, she supported her, and the patient said that her mother had understood her, which very much reassured her.

In the sixth month of the therapy, the patient mentioned a blanket she had started knitting during the treatment. Initially using brown yarn, she said she finished the last part using pink and white yarn. She 
stated that this blanket was a concrete expression of her change process, and she wanted it to stay in a place where she could always see it. During this process, she was looking more after her son, went to take driving lessons, and was looking for a job - she said she wanted to work. Approximately for the last three months of pharmacotherapy and therapeutic sessions, she had not experienced any fainting episodes; her depressive symptoms had significantly decreased and she had not shown any dissociative symptoms (HAM-D=6, BPRS=5).

The patient's therapy went on with biweekly controls during the first six months and subsequently monthly control visits. At the end of the first year, the medication was phased out. The patient's depressive symptoms resolved, she went to work, her social relations improved significantly, and her functionality was much better. We received verbal and written consent from the patient to publish this case report.

\section{DISCUSSION}

For the treatment of CD, first of all a detailed assessment is required to ascertain that the person does not suffer from any organic disorder. In planning therapy, we need to generate a biopsychosocial model considering not only factors triggering and perpetuating the disease and causing the patient's disposition, but also the individual's mental state, position in their family and in society, and any problems being present (26). It has been reported that in the treatment of $\mathrm{CD}$, the most effective plan is combining antidepressant medication with an appropriate psychotherapy and a multidisciplinary rehabilitation focusing on the improvement of the patient's functional level or the reduction of subjective problems (27). Cases with psychiatric comorbidities in particular require psychopharmacological support (28). Monodrama, which is based on role play and well received especially by young patients, allows for direct or indirect behavioral and cognitive as well as classical psychodynamic interventions. While the patient is in the focus of this type of therapy, role distribution within the family can also be assessed (21). In this sense, the use of monodrama in CD has been considered beneficial. While no studies regarding the application of psychodrama in CD were found, it has been stated that this therapy approach has a positive effect on depression (29-31). The results confirm that psychodrama can be used in the treatment of depression, as it stimulates spontaneity and creativity, thus improving depression symptoms such as reduced amount of speech, impoverished associations, and low or slow activity. It has been reported that psychodrama improved depression and contributed to personal development (32). Costa et al. (33) used a more structured and shorter modification of this therapy, called "brief and focal psychodramatic psychotherapy," in patients with mild to moderate depression. They treated one patient group only with pharmacotherapy, while another group additionally received psychotherapy. In the second group, the severity of depression decreased more and social adjustment measures increased. We assume that in our case, too, psychotherapy (mainly using monodrama techniques) provided alongside drug treatment contributed significantly to the therapy. Psychodrama allowed our patient to acknowledge and express her feelings towards her sister and husband. Through the use of role reversal techniques, she was able to look from the outside at the problematic pairwise relationships she had experienced and her own position within these relationships. Our patient benefited from the holistic therapy, the conversive faintings did not recur during the process, depressive complaints resolved, no dissociative symptoms occurred, relations with her mother improved, and her functionality changed in a positive way.

Conversion symptoms are historically linked with the hysteria concept and closely related with signs of dissociative disorder. Pierre Janet conceptualized hysteria as a dissociative disorder and defined medically unexplained somatic symptoms in trauma patients as characteristics of this state (34), while Freud (35) later indicated that the somatic symptoms of hysteria are an outcome of the defense mechanism repression and that they are conversion symptoms. 
The relation between these two clinical presentations in the diagnostic systems has changed over time. In the DSM-II, conversion and dissociative hysterical neurosis types were classified as varieties of a single disorder. DSM-III and later versions considered dissociative disorders as a separate group, while CD was classified under somatoform disorders. The ICD-10 classified all symptoms of hysterical neurosis under "dissociative (conversion) disorders." Interest in the relationship between the two diagnoses increased due to modifications in the DSM-5 chapters on somatoform and dissociative disorders that include CD. Leaving aside the diagnostic categories, recent studies have also proved a connection between medically unexplained somatic symptoms and dissociative disorders. In $30.5-47.7 \%$ of patients with CD, comorbidity of dissociative disorder according to DSM-IV has been seen $(36,37)$. While the effectiveness particularly of psychodynamic psychotherapy and cognitive psychotherapy for symptoms of depersonalization/derealization disorder has been mentioned (38), the efficacy of monodrama is not known. As the patient's depersonalization/ derealization-type dissociative symptoms did not cause clinically conspicuous problems and did not affect her functionality significantly, she was not classified according to this diagnostic category; however, in the later stages of therapy, no recurrence of these symptoms was observed. The effect of monodrama on dissociative symptoms will require more detailed investigation.

CD patients have been described as persons with problems in oral communication who tend to use body language when experiencing difficulties expressing their problems verbally. In persons with difficulties expressing their feelings, physical symptoms may represent their body language, functioning as a means of communication or a call for help (39). Therefore, we assumed that in the treatment of our patient for CD symptoms, an examination of problems that she was unable to verbalize through psychotherapy would play an important role. Monodrama technique, used in the treatment of various psychiatric disorders, should solve our patient's relationship problems; the verbalization of feelings and thoughts that she had not been able to express should be facilitated with the help of these techniques, resulting in insight that would be helpful for the therapy. We also concluded that an improvement of the patient's interpersonal relations and addressing her cognitive errors such as mind reading and personalization in therapy sessions would contribute to the recovery process.

In conclusion, this presentation underlines the benefit of a holistic approach in the treatment of a patient with $\mathrm{CD}$ and major depression comorbidity, a picture frequently encountered in Turkey. Our patient benefited from psychotherapy administered alongside drug treatment, and we believe that the joint application of both therapeutic approaches increased the effectiveness of the treatment.

\begin{tabular}{|l|l|l|}
\hline \multicolumn{2}{|l|}{ Contribution Categories } & Author Initials \\
\hline \multirow{4}{*}{ Category 1} & Concept/Design & O.K.K., S.M.A., F.I. \\
\cline { 2 - 3 } & Literature review & O.K.K., S.M.A., F.I. \\
\cline { 2 - 3 } & Data analysis/Interpretation & O.K.K., S.M.A., F.I. \\
\cline { 2 - 3 } & Case follow-up (if applicable) & O.K.K., S.M.A. \\
\hline \multirow{3}{*}{ Category 2} & Drafting manuscript & O.K.K., S.M.A. \\
\cline { 2 - 3 } & Critical revision of manuscript & O.K.K., S.M.A., F.I. \\
\hline Category 3 & Final approval and accountability & O.K.K., S.M.A., F.I. \\
\hline \multirow{3}{*}{ Other } & Technical or material support & N/A \\
\cline { 2 - 3 } & Supervision & N/A \\
\cline { 2 - 3 } & Securing funding (if applicable) & N/A \\
\hline
\end{tabular}

Informed Consent: Written consent was obtained from the participants.

Peer-review: Externally peer-reviewed.

Conflict of Interest: Authors declared no conflict of interest.

Financial Disclosure: Authors declared no financial support. 


\section{References}

1. Guggenheim GF. Somatoform Disorders: In Sadock BJ, Sadock VA (editors). Kaplan \& Sadock's Comprehensive Textbook of Psychiatry. Seventh ed. Philadelphia: Lippincott Williams \& Wilkins Publishers, 2000, 3097-3114.

2. Salgirtay A. A Study on Emergency Patients Presenting to the Psychiatry Clinic of Ankara University in the Course of One Year. Specialization Thesis, Ankara University Medical Faculty, 1979. (Turkish)

3. Bediz AU, Aydemir C, Basterzi AD, Kisa C, Cebeci S, Goka E. Physicians' attitudes towards patients with conversion disorder. 37th National Congress of Psychiatry, abstract book, 2001, 78-79. (Turkish)

4. Ford CV, Folks DG. Conversion disorders: an overview. Psychosomatics 1985; 26:371-374, 380-383. [CrossRef]

5. Isik E. Neuroses. First ed. Ankara: City Printshop, 1996, 299-312. (Turkish)

6. Widiger TA, Mullins-Sweatt SN. Categorical and dimensional models of personality disorders: In Oldham JM, Skodol AE, Bender DS (editors). Textbook of Personality Disorders. First ed. Washington: American Psychiatric Publishing Inc., 2005, 35-57.

7. Ulusahin A, Ozturk MO. Mental Health and Disorders. Thirteenth ed. Ankara: Danube Printing, 2015, 398-408. (Turkish)

8. Ozen S, Ariciogullari Z. Neuroleptic induced pharyngeal dystonia occuring at a conversion disorder background: a case report. Bulletin of Clinical Psychopharmacology 2000; 10:22832. (Turkish)

9. Kaygisiz A, Alkin T. Comorbidity of axis-I and axis-II mental disorders in conversion disorder. Turk Psikiyatr Derg 1999; 10:33-39. (Turkish)

10. Dilbaz N, Bitlis V, Dogan S, Usseli I, Erdogan S. Psychiatric symptoms in patients with a diagnosis of conversion disorder. Dusunen Adam The Journal of Psychiatry and Neurological Sciences 1994; 7:5-9. (Turkish)

11. Bowman ES, Markand ON. Psychodynamics and psychiatric diagnoses of pseudoseizures subjects. Am J Psychiatry 1996; 153:57-63. [CrossRef]

12. Kroenke K. Efficacy of treatment for somatoform disorders: a review of randomized controlled trials. Psychosom Med 2007; 69:881-888. [CrossRef]

13. Khalil TM, Abdel-Moty E, Asfour SS, Fishbain DA, Rosomoff RS, Rosomoff HL. Functional electric stimulation in the reversal of conversion disorder paralysis. Arch Phys Med Rehabil 1988; 69:545-547.
14. Erol O. Psychotherapeutic interview. Turkiye Klinikleri J Psychiatry-Special Topics 2009; 2:45-51. (Turkish)

15. Diseth TH, Christie HJ. Trauma-related dissociative (conversion) disorders in children and adolescents-an overview of assessment tools and treatment principles. Nord J Psychiatry 2005; 59:278292. [CrossRef]

16. Hopp JL, LaFrance WC Jr. Cognitive behavioral therapy for psychogenic neurological disorders. Neurologist 2012; 18:364372. [CrossRef]

17. Kellerman PF. Focus on Psychodrama. London: Jessica Kingsley Publ. 1992, cit. from the Turkish transl. Psikodramaya Derinlemesine Bakis. Gokler B, Gokler Danisman I, Mavili Aktas A (translation ed.) First ed. Ankara: Nobel Publishing, 2013. (Turkish)

18. Ozbek A, Leutz G. On-Stage Interaction in Psychodrama Group Therapy. Second ed. Ankara: Abdulkadir Ozbek Psychodrama Institute Publ., 2003, 31-51. (Turkish)

19. Yavas I. Use of monodrama in the treatment of prolonged grief reaction, a case report. $22^{\text {nd }}$ International Congress of Group Psychotherapy, Proceedings Book, 1998, 179-188. (Turkish)

20. Ozdel O, Atesci F, Kalkan-Oguzhanoglu N. An anorexia nervosa case and an approach to this case with pharmacotherapy and psychodrama techniques. Turk Psikiyatri Derg 2003; 14:153-159. (Turkish)

21. Cohen D, Delaroche P, Flament MF, Mazet P. Case report: individual psychodrama for treatment resistant obsessivecompulsive disorder. Neuropsychiatr Enfance Adolesc 2014; 62:19-21. [CrossRef]

22. Okyayuz HU. The Use of Monodrama and Psychodrama Methods in the Psychotherapy of Borderline Patients. Unpublished final paper in psychodrama, Dr Abdulkadir Ozbek Psychodrama Institute, Ankara, 2000. (Turkish)

23. Babaoglu AN. Monodrama and Catathymic Image Experience Techniques Used Jointly and Mutually in Individual Psychotherapy. Unpublished final paper in psychodrama, Istanbul, 1997. (Turkish)

24. Ozer-Danis G, Uneri OS. A lesser known aspect of psychodrama: monodrama. Klinik Psikiyatri Dergisi 2017; 20:238-242. (Turkish)

25. Dogan O. Conversion disorder: In Gulec C, Koroglu E (editors). Basic Book of Psychiatry. Second ed. Ankara: Physicians' Publication Union, 2007, 377-385. (Turkish) 
26. Basar HM. Executive Functions and Dissociative Symptoms in Conversion Disorder Patients. Specialization Thesis in Medicine, Ministry of Health, Istanbul Bakirkoy Prof. Dr. Mazhar Osman Research and Training Hospital for Psychiatry-Neurology and Neurosurgery, Dept. for Mental Health and Diseases, Istanbul, 2015. (Turkish)

27. Allin M, Streeruwitz A, Curtis V. Progress in understanding conversion disorder. Neuropsychiatr Dis Treat 2005; 1:205-209.

28. Fritz GK, Campo JV. Somatoform disorders: In Lewis M (editor). Child and Adolescent Psychiatry: A Comprehensive Textbook. Third ed. Philadelphia: Lippincott Williams \& Wilkins Publishers, 2002, 847-858.

29. Ackerman M, Ackerman S. The use of psychodrama in a postpartum depression. J Am Coll Neuropsychiatr 1962; 1:67-70.

30. Burwell D. Psychodrama and the depressed elderly. Can Nurse 1977; 73:54-55

31. Rezaeian MP, Sen AK, Sen-Mazumdar DP. The usefulness of psychodrama in the treatment of depressed patients. Indian J Clin Psychol 1997; 24:82-88.

32. Uysal S. The Contribution of the Psychodrama Method to Depression Therapy in Group Psychotherapy. Final paper in psychodrama, Dr. Abdulkadir Ozbek Psychodrama Institute, Ankara, 2007. (Turkish)
33. Costa EM, Antonio R, Soares MB, Moreno RA. Psychodramatic psychotherapy combined with pharmacotherapy in major depressive disorder: an open and naturalistic study. Braz J Psychiatr 2006; 28:40-43. [CrossRef]

34. van der Kolk BA, van der Hart O. Pierre Janet and the breakdown of adaption in psychological trauma. Am J Psychiatry 1989; 146:1530-1540. [CrossRef]

35. Freud S, Breuer J. Studies on hysteria. Human Emotions: A Reader, 30, 1998

36. Tezcan E, Atmaca M, Kuloglu M, Gecici O, Buyukbayram A, Tutkun H. Dissociative disorders in Turkish inpatients with conversion disorder. Compr Psychiatry 2003; 44:324-330. [CrossRef]

37. Sar V, Akyuz G, Kundakci T, Kiziltan E, Dogan O. Childhood trauma, dissociation, and psychiatric comorbidity in patients with conversion disorder. Am J Psychiatry 2004; 161:2271-2276.

\section{[CrossRef]}

38. Coons PM. Depersonalization and Derealization: In Michelson LK and Ray WJ (editors). Handbook of Dissociation: Theoretical, Empirical, and Clinical Perspectives. Springer Science \& Business Media, 1996, 291-305. [CrossRef]

39. Kozlowska K. The developmental origins of conversion disorders. Clin Child Psychol Psychiatry 2007; 12:487-510. [CrossRef] 